\title{
دلالات الحذف في الجملة الاسمية مع التطبيق على نماذج من الأحاديث النبوية
}

د. درويش عبد القادر الكجك

جامعة القصيم كلية العلوم والآداب بعقلة الصقور دروليد 


\section{لــــاتلات الحذف في الجملة الاسمية مع التطبيق على نماذج من الأحاديث النبوية}

\section{مقدمة}

قد يرى المتكلم البليغ الذواق للأدب الرفيع أن يحذف مد من كلامه الذي يريد توصيل

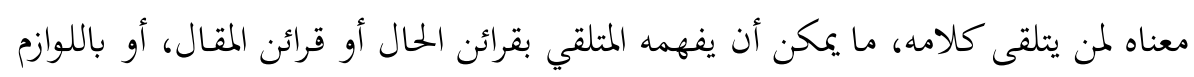

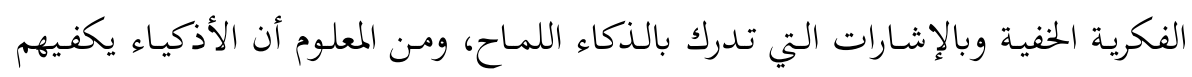
الإلماح، لأفم يدركون المقاصد باللمح.

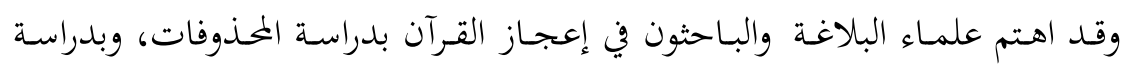

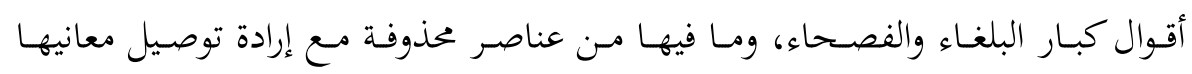

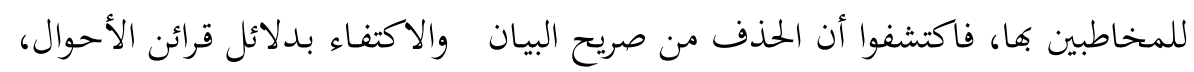

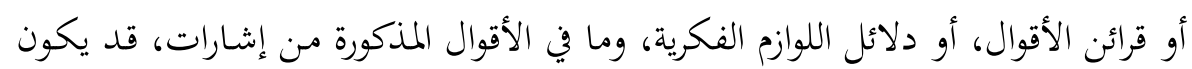

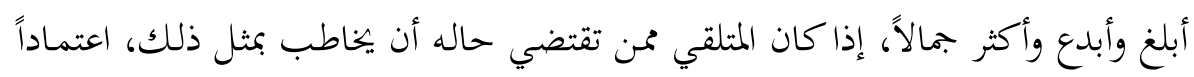

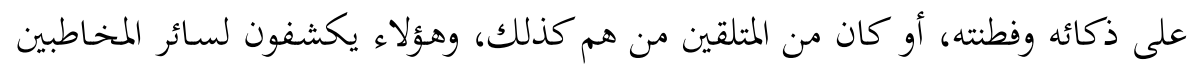

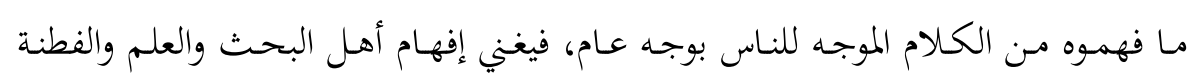

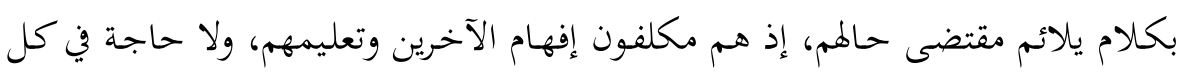

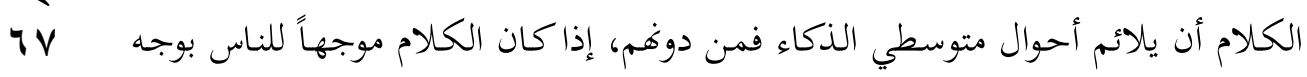

ولذلك نجد أن في كلام الله تعالى الموجه للناس أجمعين ما يمكن أن يفهمه بسهولة كل المخاطبين، ونجد فيه ما يحتاج فهمه إلى ذكاء متوسط أو فوق المتوسط ونجد فيه ما يحتاج

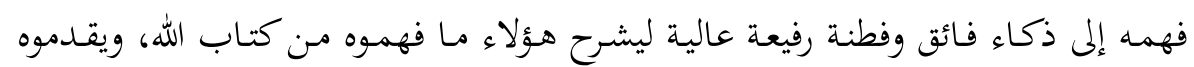

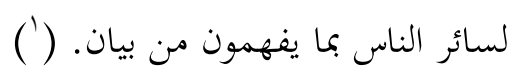

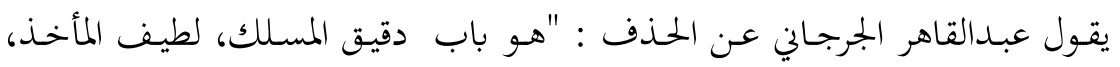

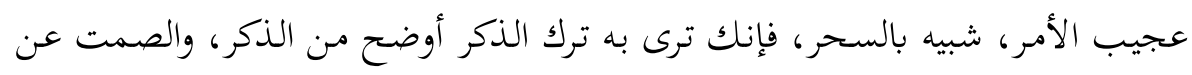

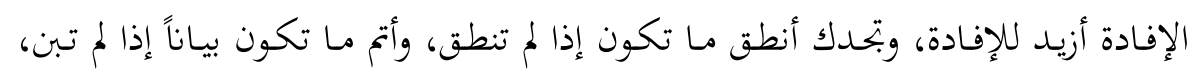

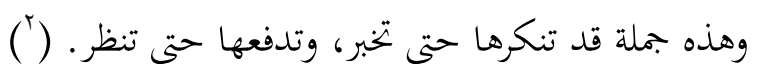

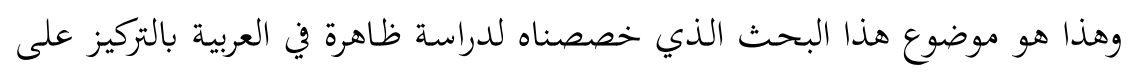

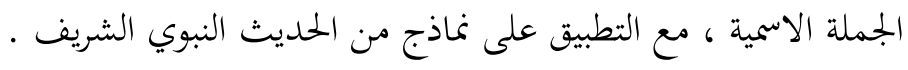




\section{أهمية البحث : - أهمث}

تكمـن أهميـة البحـث في كونسه يتتبع ظـاهرة مـن الظواهر التي تسـري في شـرايين اللغـة العربية، وله وجوده الذي يكشف عن عبقرية هذه اللغة مراعاة للخفة ، ومن ثم ابتهتُ لبيان هذه الظاهرة وتسليط الضوء عليها من خلال ورودها في بعض الأحاديث النبوية الشريفة .

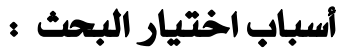

محـا لاشـك فيـه أنّ السـنة النبويـة المطهـرة هي المصـدر الثـاني للتشـريع بعـد كتـاب الله تعالى، فهي تُعد من المصادر المتفق عليها لدى المسلمين ، وهي جامعة لا تفوتا شاردة ولا

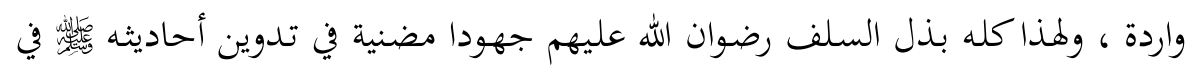

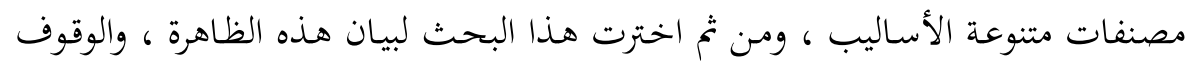

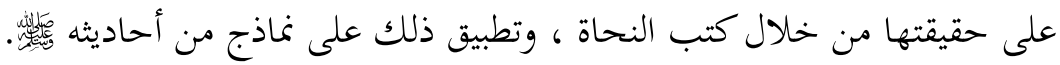

\section{منهجية البحث :}

اقتضت منهجية البحث أن يكون من خلال المنهج الوصفي الاستقرائي •

$$
\text { تقسيم البحث : }
$$

وقد قسمته إلى مقدمة وتمهيد وأربعة مباحث وخاتمة .

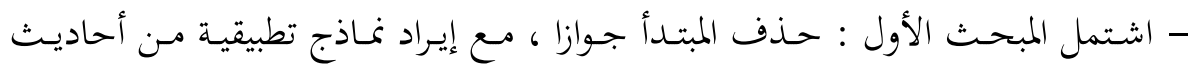

الرسول

- واشـتمل المبحـث الثـاني :حـذف المبتـدأ وجـوبا ، مـع إيـراد نمـاذج تطبيقيـة مـن أحاديـث الرسول

- واشتمل المبحـث الثالث :حذف الخـبر وجـوبا ، مع إيراد نماذج تطبيقيـة مـن أحاديـث

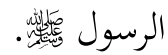

- واشتمل المبحث الرابع :حذف الخبر جوازا ، مع إيراد نماذج تطبيقية من أحاديث الرسول

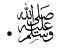

\section{تقمهيد:}

المبتدأ والخبر ركنان أساسيان في الجملة الاسمية ، وتحصل الفائدة بمجموعهما فلابد منهما، إلا أنه قد توجد قرينة لفظية أو حالية تغني عن النطق بأحدهما، فيحذف لدلالتها عليه ؛ لأن

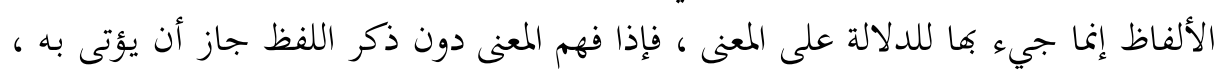
ويكون مراداً حكماً وتقديراً. 


\section{لـالات الحذف في الجملة الاسمية مع التطبيق على نماذج من الأحاديث النبوية}

وقد جاء ذلك مجيئاً صالحاً، فحذفوا المبتدأ مرة، والحبر أخرى، فمما حذف فيه المبتدأ

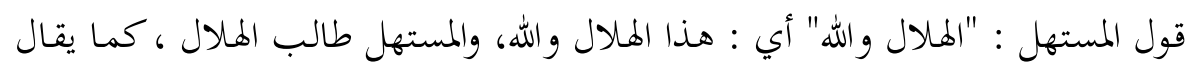

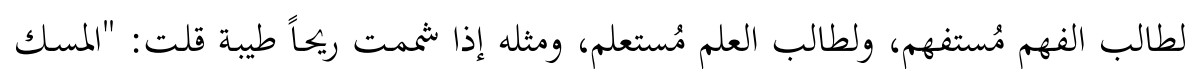

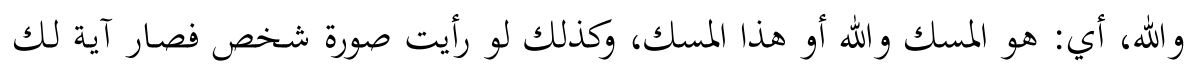

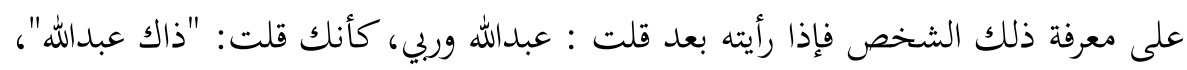

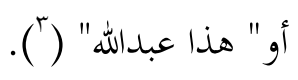

معنى الحذف في اللغة: القطع والإسقاط؛ جاء في الصحاح: "حَذْفُ الشيء:

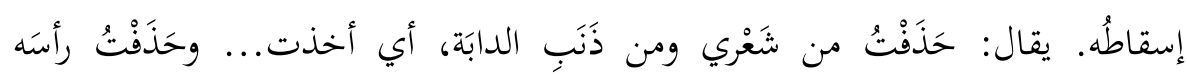

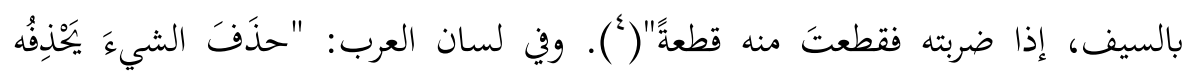

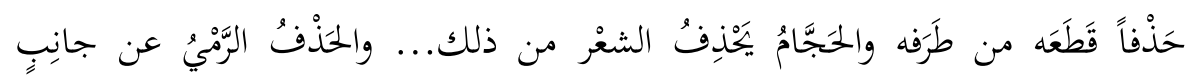

والضرْبُ "( )

\section{واصطلاحَا : إسقاط جزء الكلام أو كله لدليل (").}

والحذف عند أهل البلاغة قسمان : قسم يَظهر فيه المحذوف عند الإعراب، كقوهم:

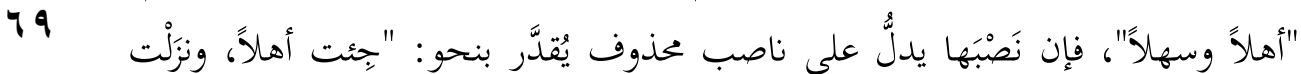

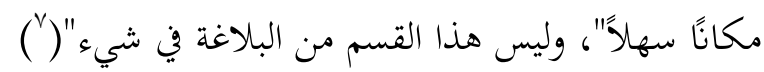

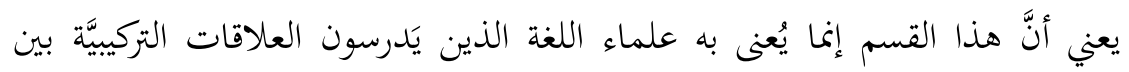

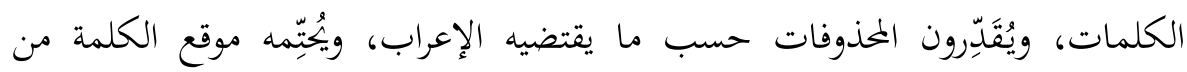

$$
\text { الإعراب. }
$$

وقسم آخر لا يَظهر فيه المحذوف بالإعراب، وإنما تَعلم مكانه إذا أنت تصفَّحت المعنى

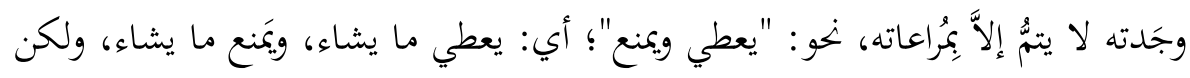

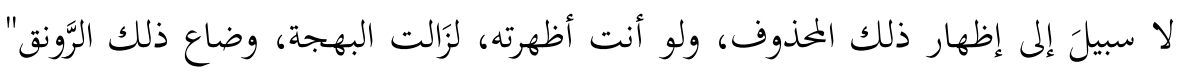

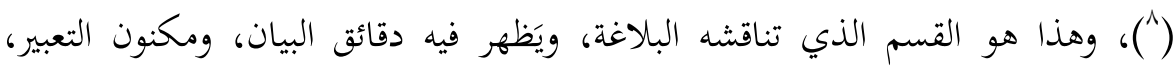

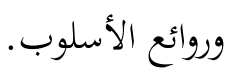

وأما عن أغراض الحذف عند البلاغيين، خصوصًا ما يتعلَّق بالمسند إليه، والتي تُعَدُّ

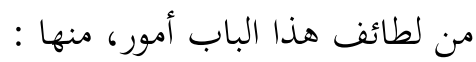




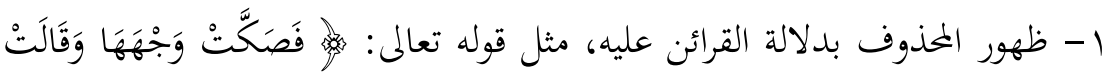

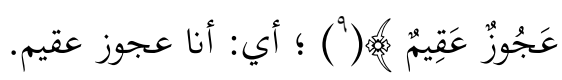

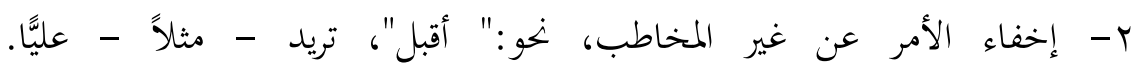

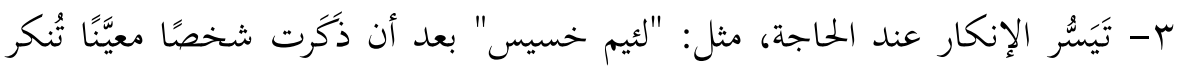
عليه أمرًا. ع - الخوف من فَوات فرصة سانحة، كقولك تُنَبّه صيَّادًا: "غزال"؛ أي: هذا غزال، فاصْطَدْه، أو نحو ذلك. ه- اختبار تَنَبُهه السامع، أو مقدار تَنَبُهه، نحو: "نوره مُستفاد من نور الشمس، أو هو واسطة عقد الكواكب"، تقصد القمر في كلا الحالتين.

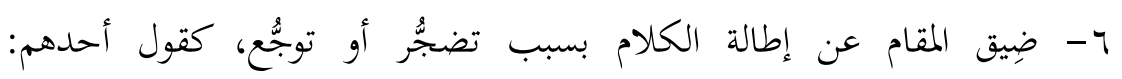

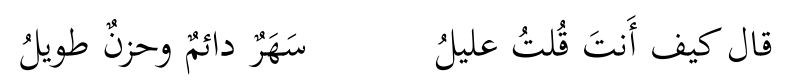

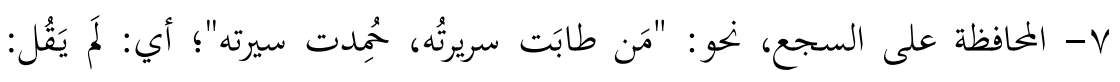
حَمِد الناس سيرته؛ للمحافظة على السجع المستلزٍِ رفْعَ الثانية. م- المحافظة على القافية، كقول أحدهم

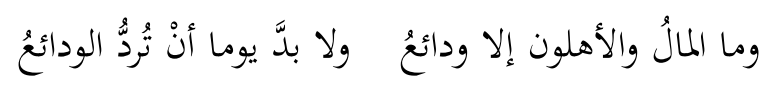

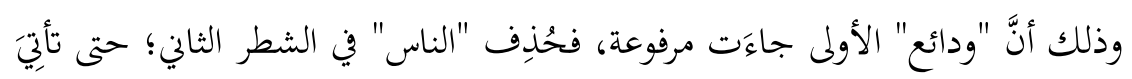

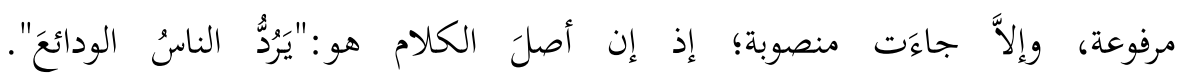
9- - المحافظة على الوزن، كقوله:

وأخلص منه لا عليَّ ولا لِيًا

$$
\text { على أني راضِ أنْ أحملَ الهوى لِي شيء، ولا عَلَيَّ شيء. }
$$

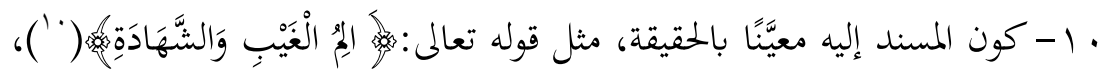
أو ادِّعاءً، نحو: وهاب الألوف؛ أي: فلان.

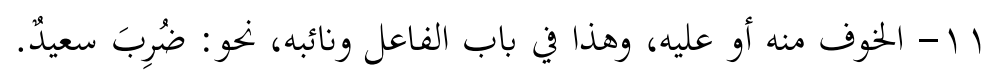
rا 


\section{المبحث الأول: حذف المبتدا جوازاً}

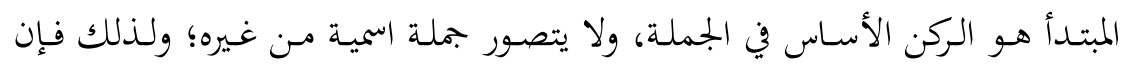

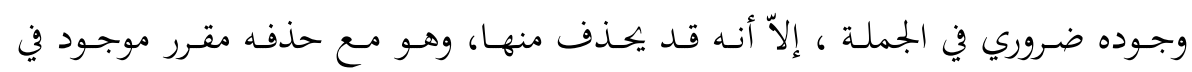

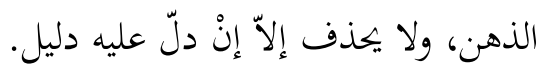
جاء في كتـاب سيبويه :" ( هـذا باب يكون المبتـدأ فيـه مضمرا ويكون المبنى عليه

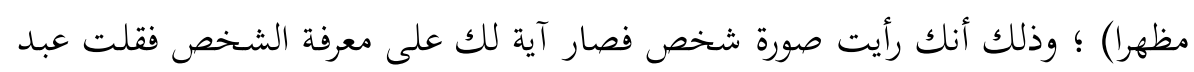

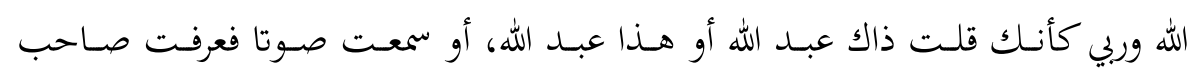

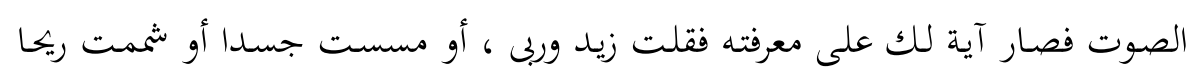

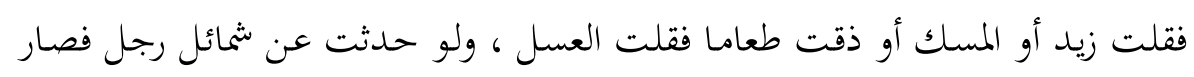

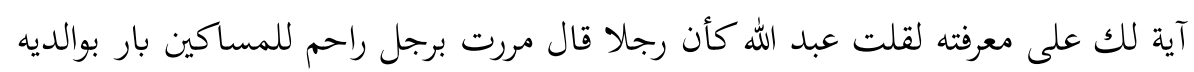

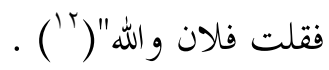

وجاء في شرح التسهيل: "ومـن حذف المبتدأ جوازاً لقرينة حذفه بعد استفهام عن

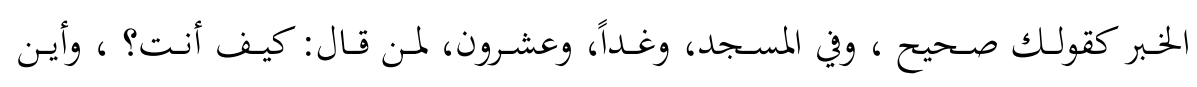
اعتكافك ؟، ومتى سفرك ؟ وكم دراهمك ؟ ؟ وفئ.

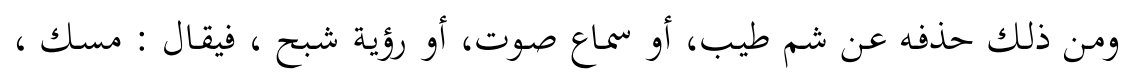

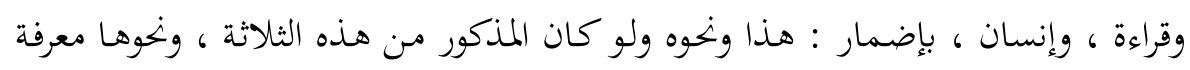

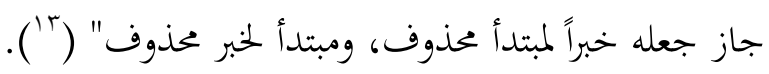

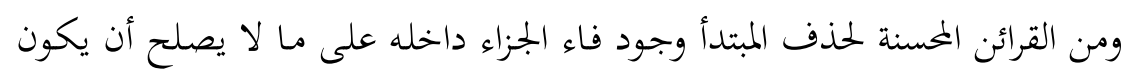

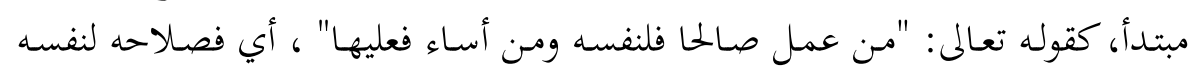

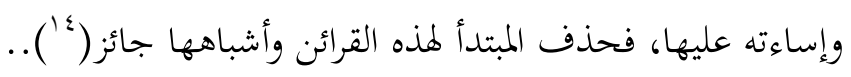

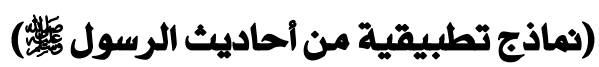

نص الحديث : عن سعيد بن المسيب عن أبي هريرة رضي الله عنه قال: قالمال الرسول رسول

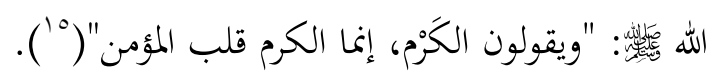

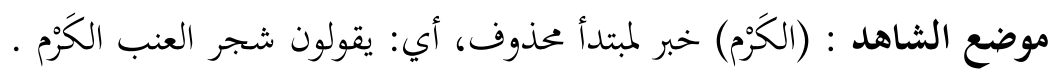

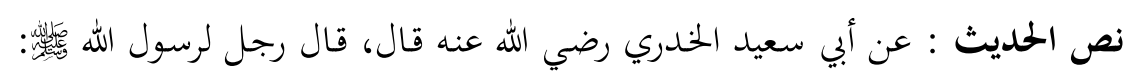

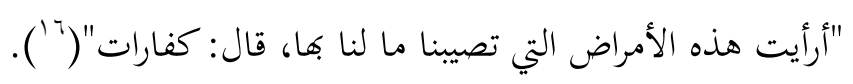




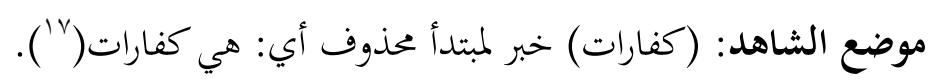

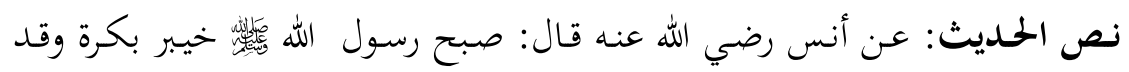

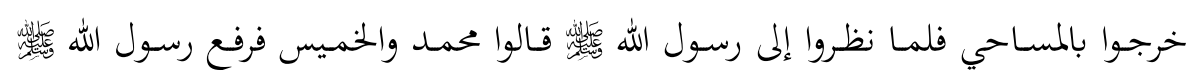

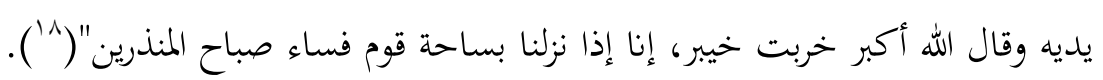

$$
\text { موضع الشاهد: (محمد) بالرفع خبر مبتدأ محذوف أي: هذا محمدُ(9) (19). }
$$

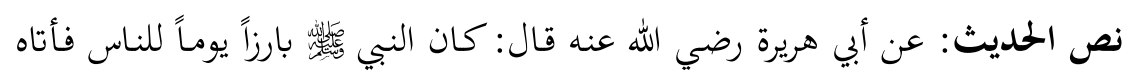

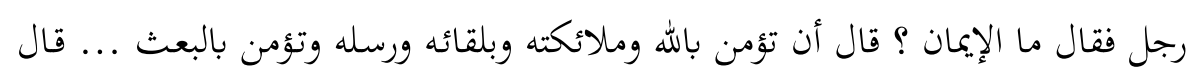

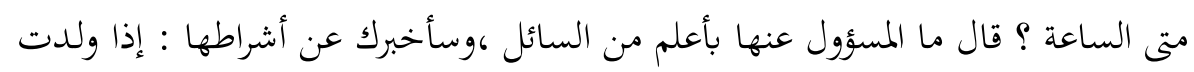

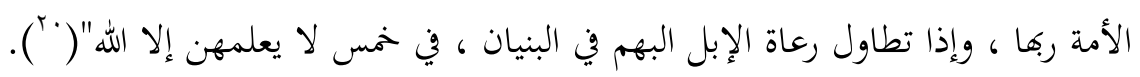

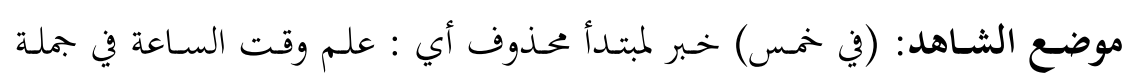

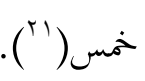

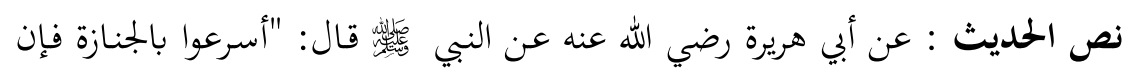

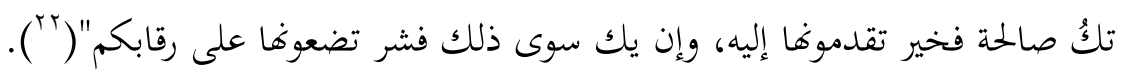

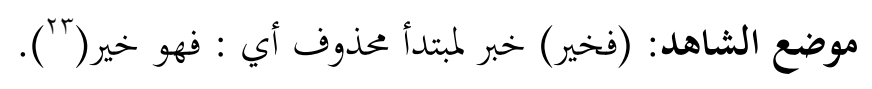

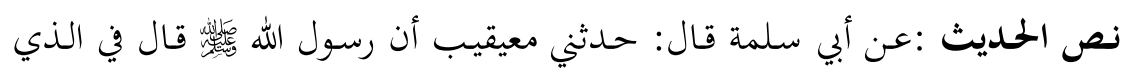

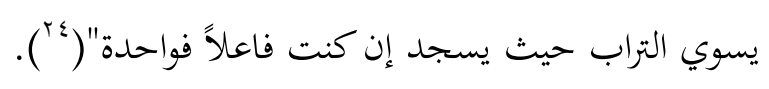

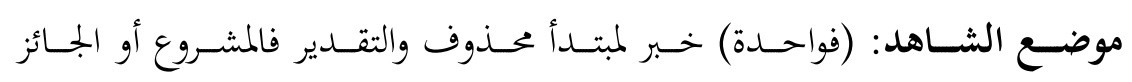

$$
\text { واحدة) }
$$

نص الحديث: عن أبي إسحق عن مسلم عن نذير عن حذيفة: "أخذ رسول الله

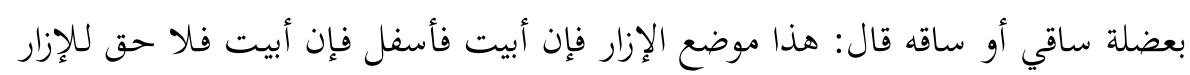

$$
\text { فيما دون الكعبين"( آن). }
$$

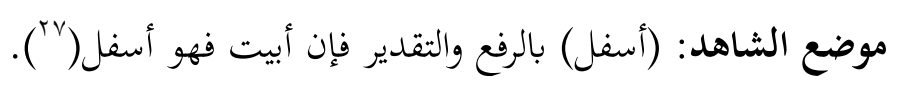

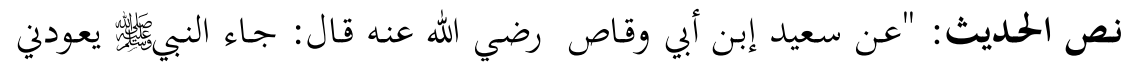

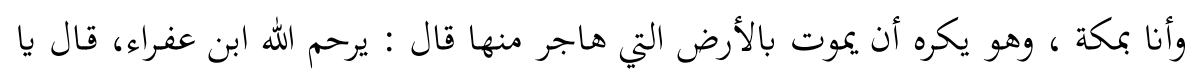

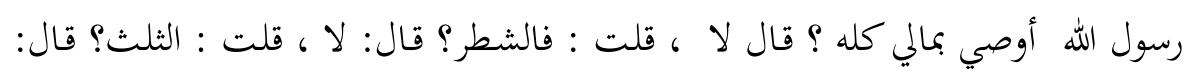




\section{لــالات الحذف في الجملة الاسمية مع التطبيق على نماذج من الأحاديث النبوية}

فالثلث والثلث كثير إنك إن تدع ورثتك أغنياء خير من أن تدعهم عالة يتكففون الناس في

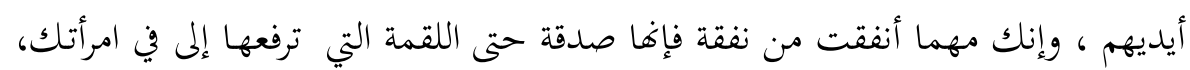

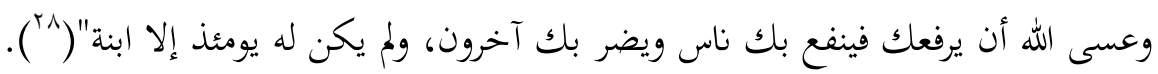

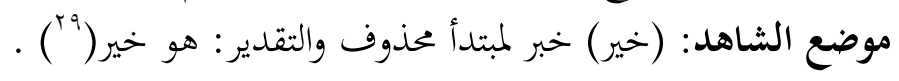

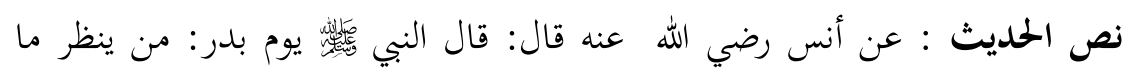
فعل أبو جهل؟ فانطلق ابن مسعود فوجده قد ضربه ابنا عفراء حتى برد ، فأخذ بلحيت أنسيته

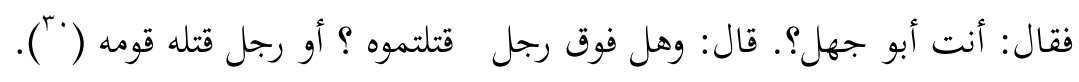
موضع الثاهد : (أنت أبو جهل) أنت مبتدأ محذوف الخبر والتقدير :أنت المقتول

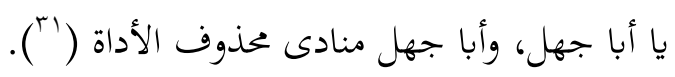

نص الحديث : عن أسامة بن زيد رضي الله عنه قال: قلت يا رسول الله إنك تصوم

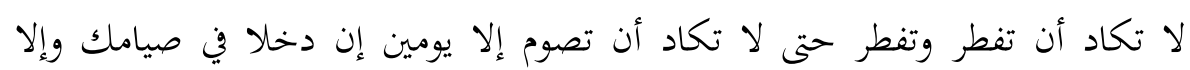

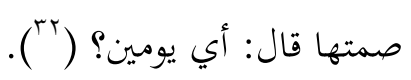

موضع الشاهد: (أي يومين) والتقدير : أي يومين هما فحذف الخبر للعلم به (بrمَ).

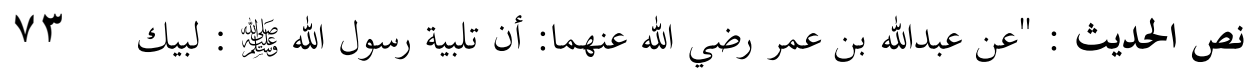

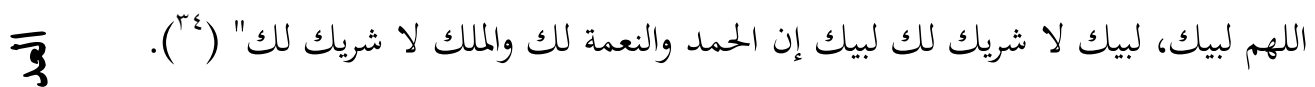

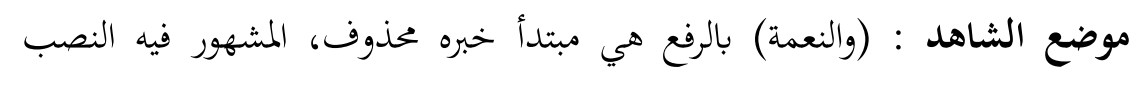

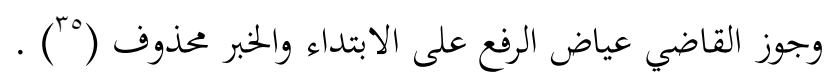

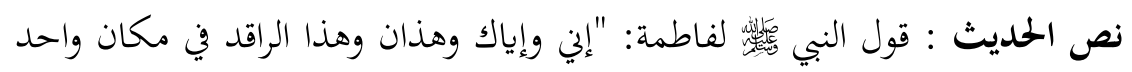

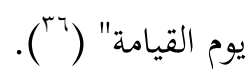

موضع الشاهد : (وهذان) وقع في هذه الرواية (هذان) بالألف.

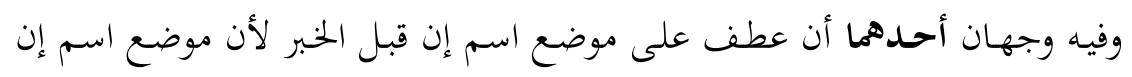
رفع تقديره أنا وأنت وهذان أحدان. والوجه الثاين : أن تكون الألف في "هذان" لازمة في كل حال، كما قالوا: ضربته بين

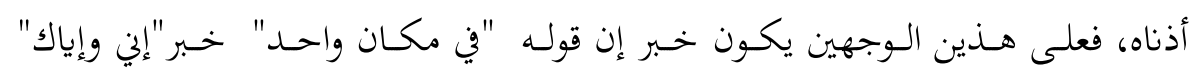

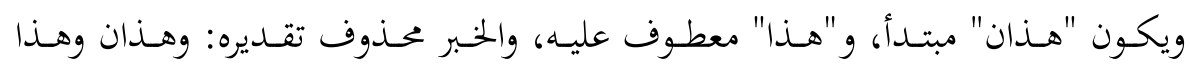


وجاء في شواهد التوضيح قوله: "وهذا وهذان "جاء على اللغة الحارثية"(مبم)

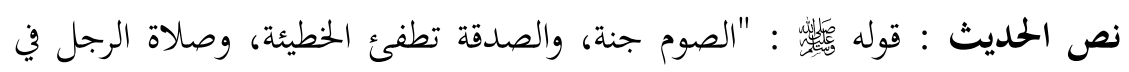

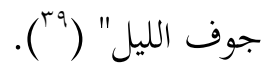
موضع الشاهد : (وصلاة الرجل) مبتدأ خبره محذوف ، أي: صلاة الرجل في جوف

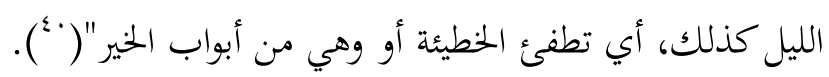

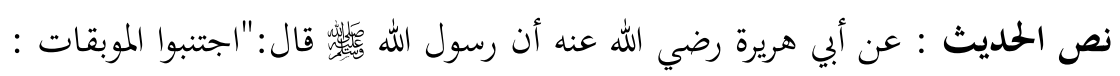

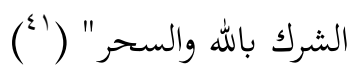
موضع الشاهد : (الشرك ، السحر) يجوز الرفع على تقدير منهن والشرك بالله والسحر" (

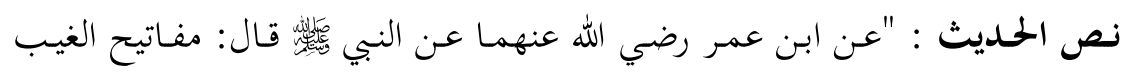

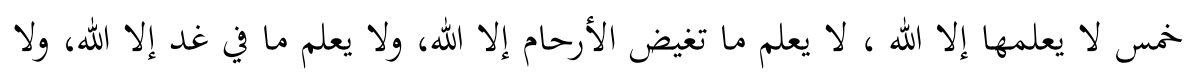

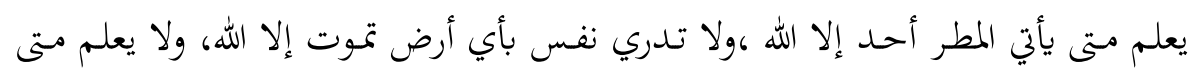

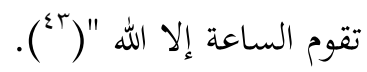

$$
\text { موضع الثاهد : (ولا تدري نفس بأي أرض تموت إلا الله). }
$$

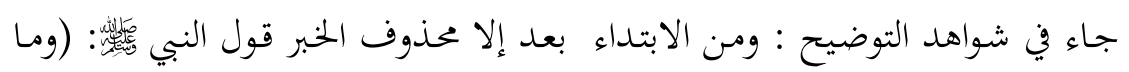
تدري نفس بأي أرض تموت إلا الله ) .

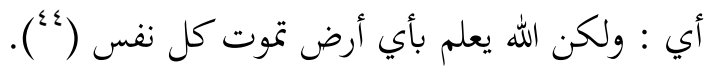




\section{المبحث الثاني : حذف المبتدأ وجوبا}

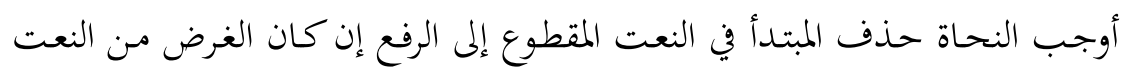

مجرد مدح أو ذم أو ترحم، وإن كان لغير ذلك جاز حذف المداه المبتدأ وذكره.

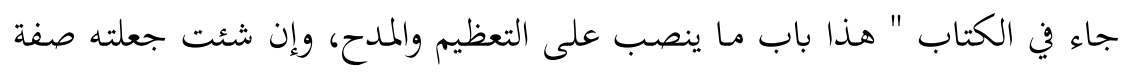
فجرى على الأول، وإن شئت قطعته فابتدأته، وذلك قولك الحمد لله الحميد هو ، الحمد الحد

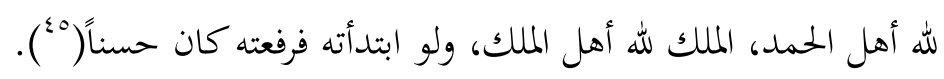

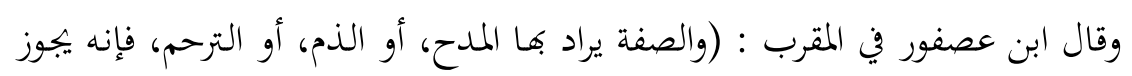

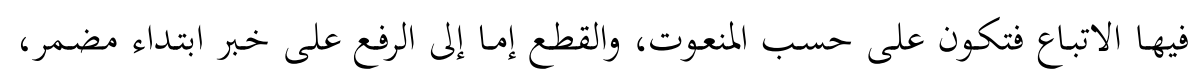

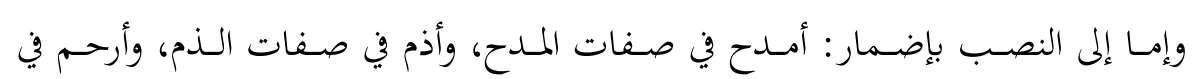
صفات الترحم. (

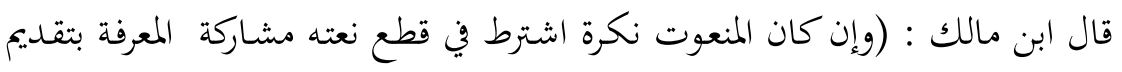

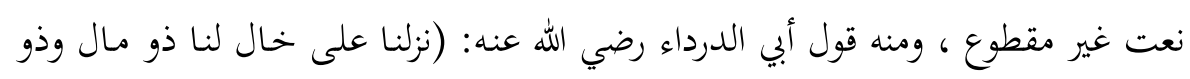
هيئة) ( ن ( والتقدير : هو ذو مال.

وأورد الصبان في حاشيته على الأشموني:( فلو كان نعت النكرة واحداً نحو جاء رجل كريم ، لم يجز قطعه إلا في الشعر، وقال بعض النحويين أن منع قطعه هو المشهور وأن أنسينه

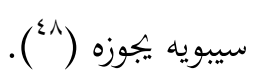

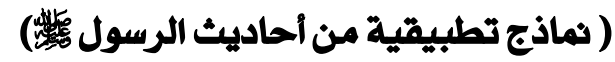

نص الحديث : عن عطاء بن سعيد الليثي عن أبي سعيد الخدري رضي المادي الله عنه أن

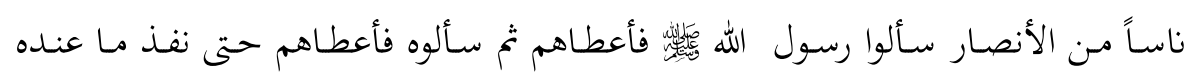
فقال: ما يكن عندي من خير فلن أدخره عنكم ومن يستغن يغنه الله ومن يصبر يصبره

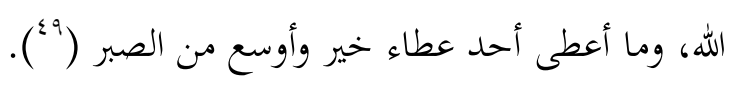
موضع الشاهد : (خير) بالرفع خبر لمبتدأ محذوف أي هو خير احسير 


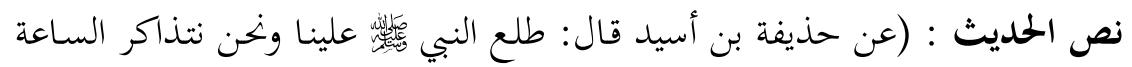

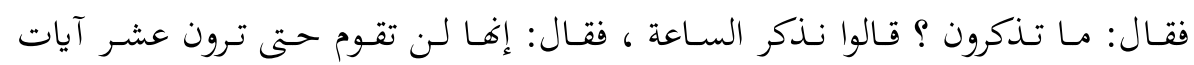

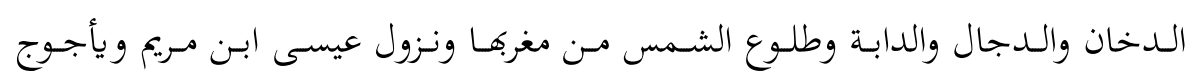

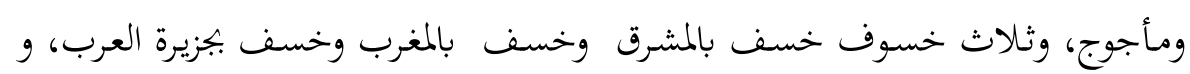

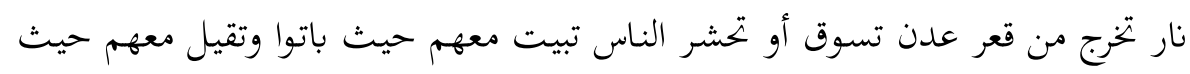
قالوا (ن).

موضع الثاهد: (طلوع الشمس ....خسف المغرب) بالرفع على تقدير : هي(10).

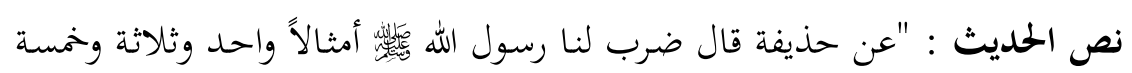

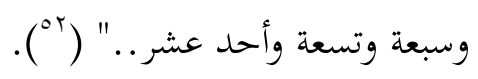

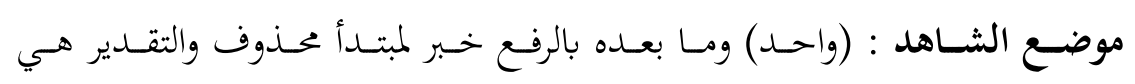
واحد)

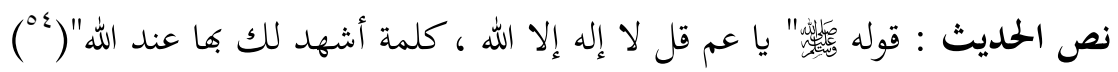

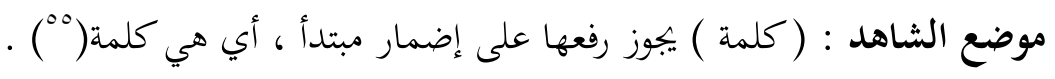

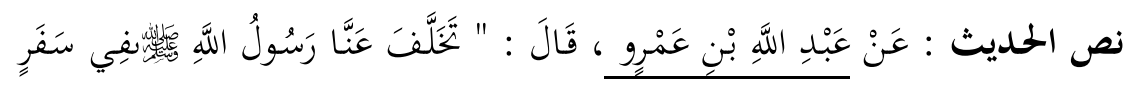

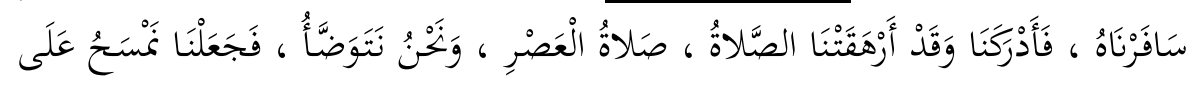

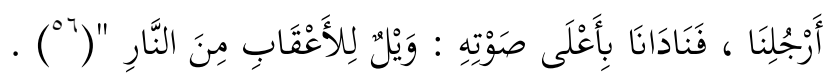

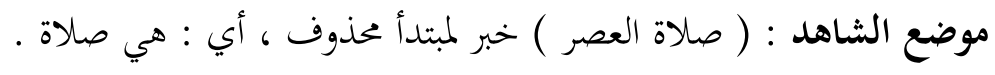




\section{المبحث الثالث حذف الخبر وجوبا}

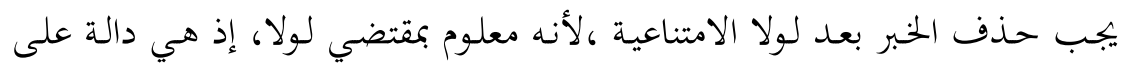

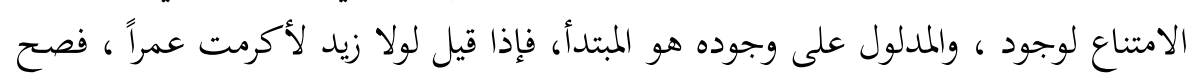
الحذف لتعيين المحذوف ،ووجب لسد الجواب مسده وحلوله ولمدول محله.

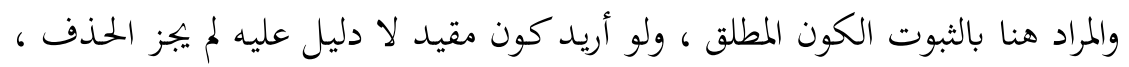

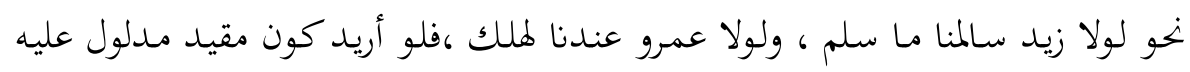

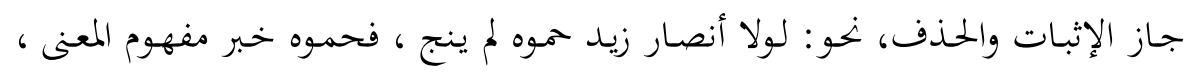
فيجوز إثباته وحذفه.

وقال الكسائي : (الاسم بعدها فاعل لفعل مقدر كما في قوله لو ذات سور لطمتني،

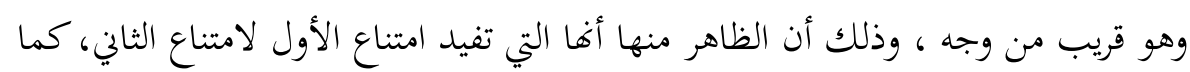

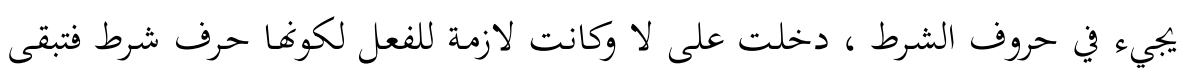
مع دخولها على لا على ذلك الاقتضاء.

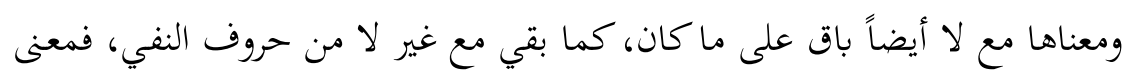

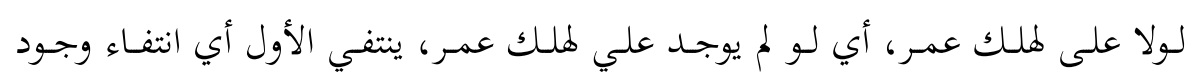

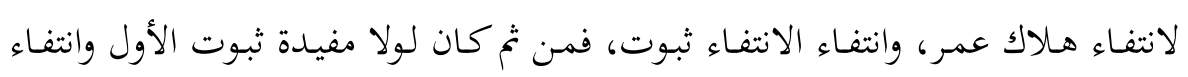

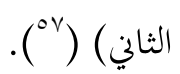

$\overline{3}$

وجاء في الارتشاف: (الخبر هو الجواب )، وقال الجمهور : (الخبر محذوف وجوباً، ولا

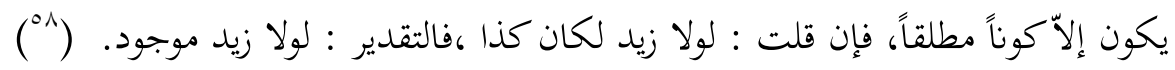

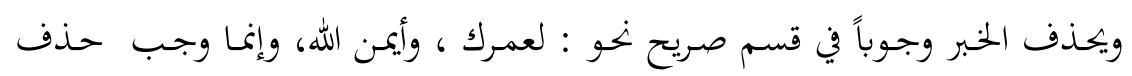

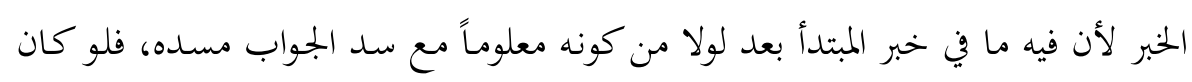

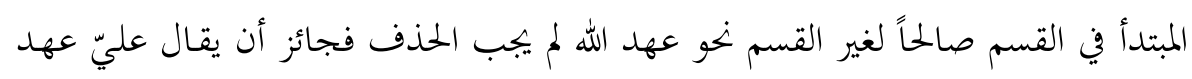

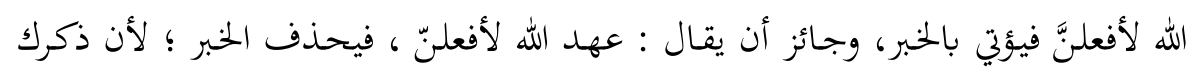

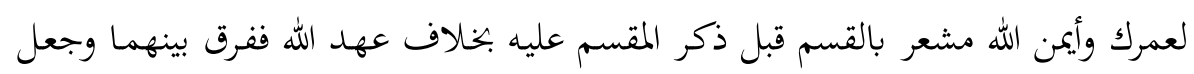

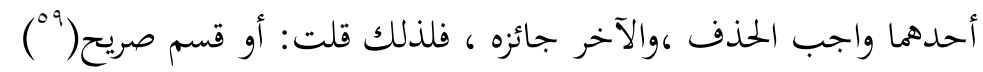

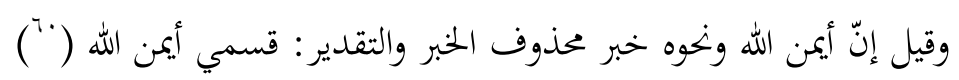


ومسن الحـذف الواجـب حذف خبر المبتـدأ بعـد واو المصـاحبة الصريحة كقولك أنت

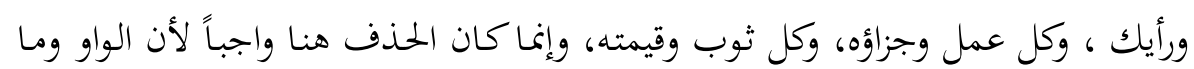

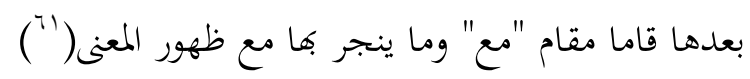

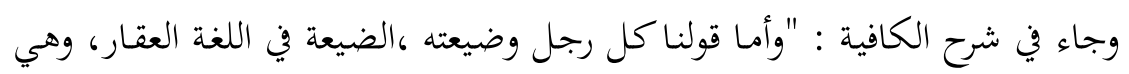
هنا كناية عن الضيعة، وضابط هذا كل مبتدأ عطف عليه بالواو التي بمعنى مع.(")

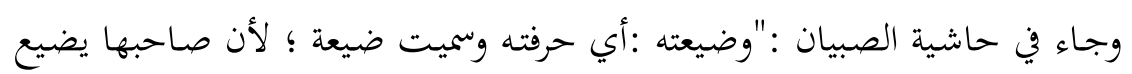

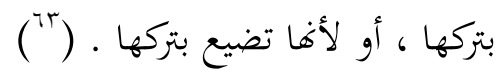
وجاء في الارتشاف :"فأما قولم كل رجل وضيعته، وكل ثوب وقيمته بما لما الواو صريحة

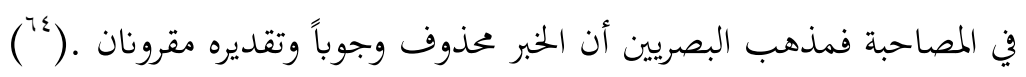
ومن الحذف الواجب كذلك حذف الخبر قبل الحال إذا كان المبتدأ أو معموله عاملاً

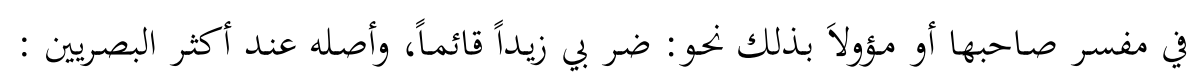

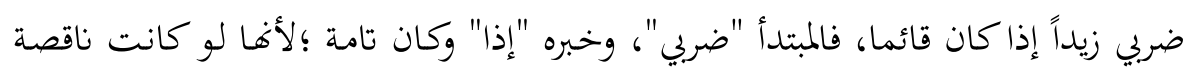

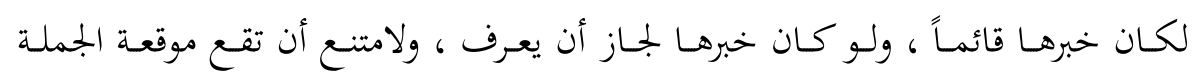
الاسمية المقرنة بواو الحال فعلم أنه حال لا خبر(

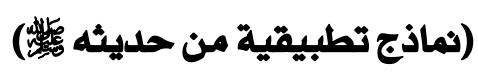

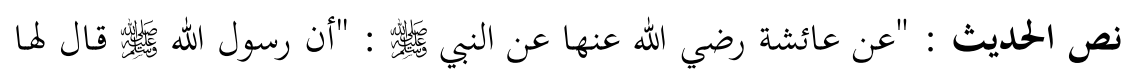

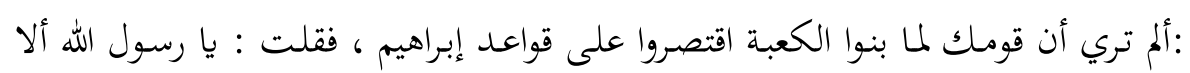

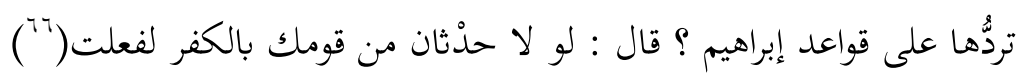

$$
\text { موضع الشاهد : (حدثان)الخبر هنا محذوف وجوباً. }
$$

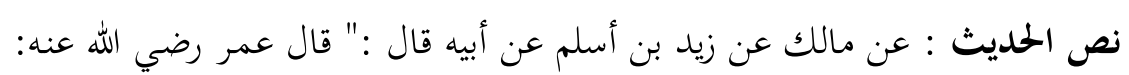

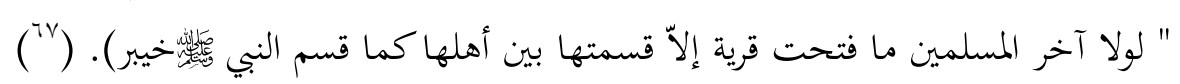

$$
\text { موضع الثاهد:(آخر) خبر المبتدأ محذوف وجوباً. }
$$

نص الحديث: "قوله له

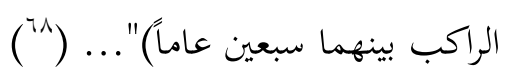




\section{لـالات الحذف في الجملة الاسمية ميع التطبيق على نماذج من الأحاديث النبوية}

موضع الشاهد : (لعمرو إلكك) الخبر محذوف وجوباً تقديره لعمرو الله قسمي ، قال في النهاية : قوله : ( لعمرو إلهك) قسم ببقاء الله ودوامـه ،وهـو رفع بالابتـداء ، والخـبر محذوف وجوبا تقديره لعمرو الله قسمي أي ما أقسم به واللام للتوكيد. (

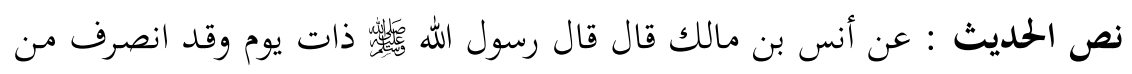

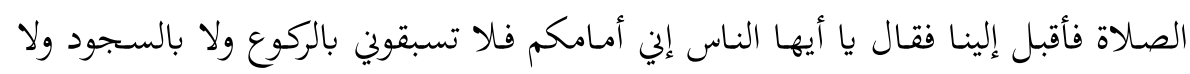

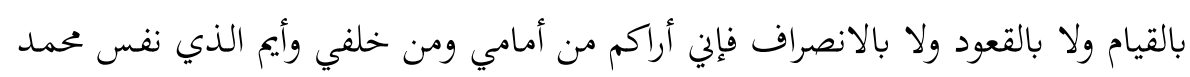

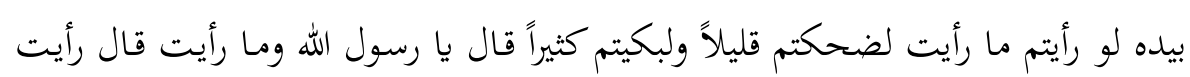

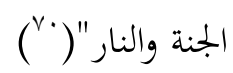

موضع الشاهد : (وايم الله) أصلها أيمن فحذفت منها النون ، وتستعمل في القسم ، وهي مرفوعة بالابتداء والخخبر محذوف، أي : أيمن الله لازمة.

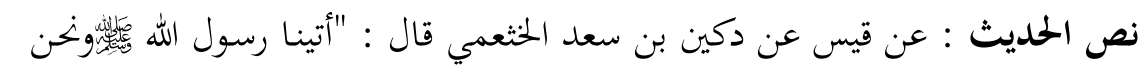

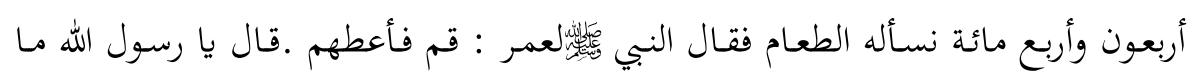
عندي إلاّ ما يقيظني والصبية. قال قم فأعطهم قال يا رسول الله سمع وطاعة ـ (

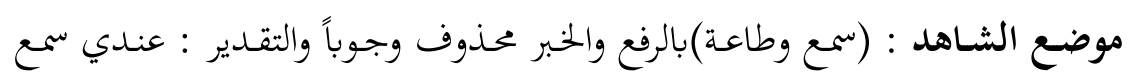

نس الحسلديث : مـن حسديث طويل لصاحبة المزادتين :"عهـدي بالمساء أمسس هـذه

$$
\text { الساعة... }
$$

موضع الشاهد : (عهدي) فعهدي مبتدأ، (بالماء) متعلق به، و (أمس) ظرف لعهدي

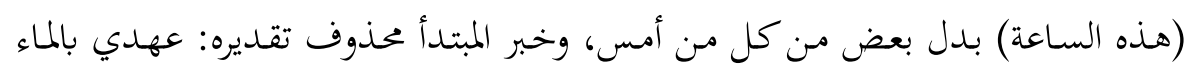
حاصل.

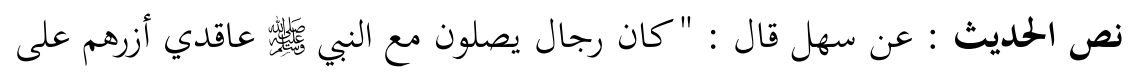

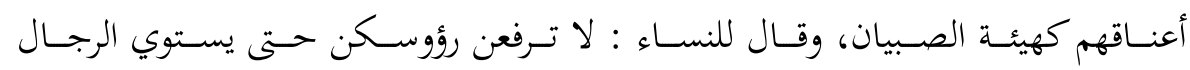

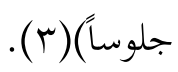


موضع الشاهد : (عاقدي أزرهم) منصوب على الحال سدت مسد الخبر المسند إلى هم والتقدير : "وهم مؤتزرون عاقدي أزرهم" (ع ).

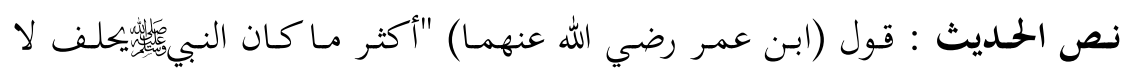
ومقلب القلوب) () (vr). موضع الشاهد : ( أكثر ) قال الطبي في المشكاة : (أكثر) مبتدأ ، و و(ما) مصدرية،

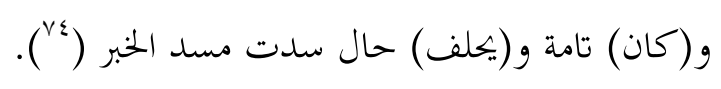

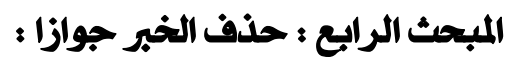

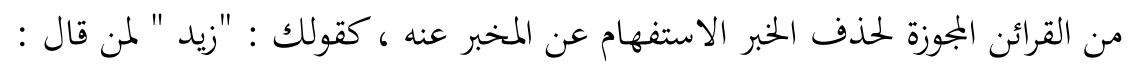

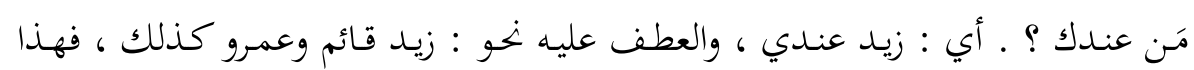

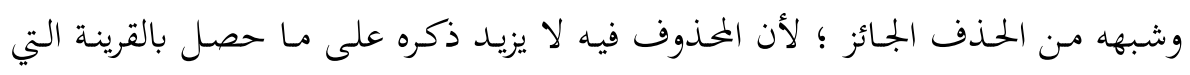

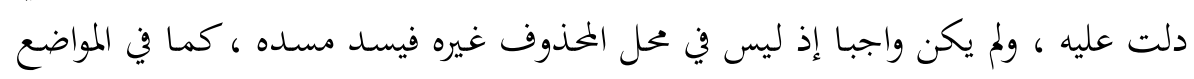

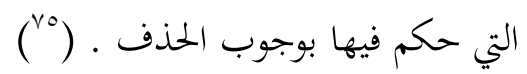

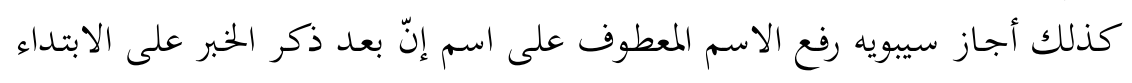

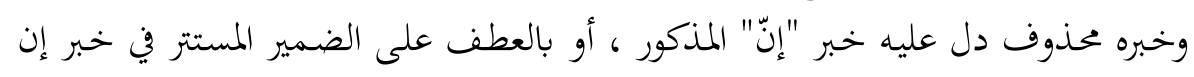

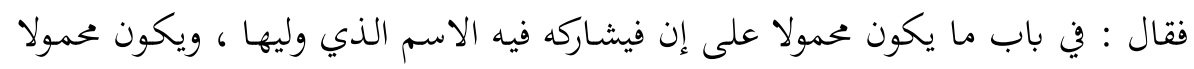

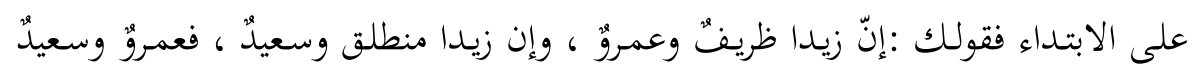

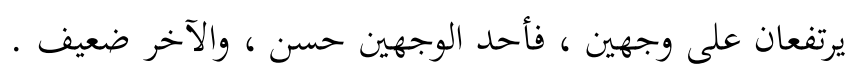

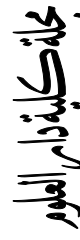

$\wedge$.

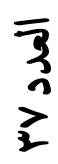

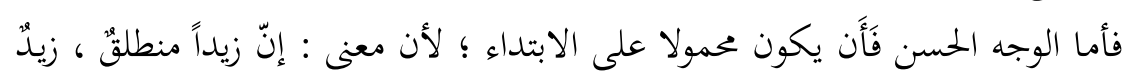

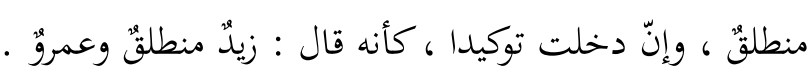

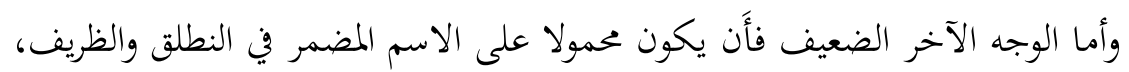

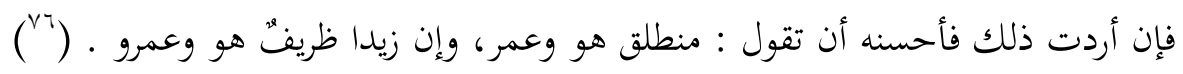

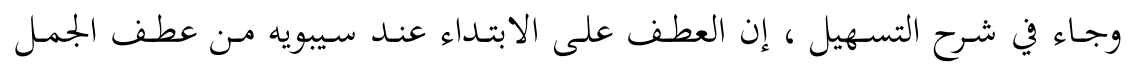

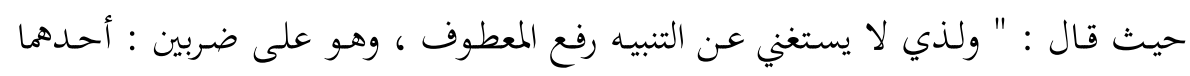

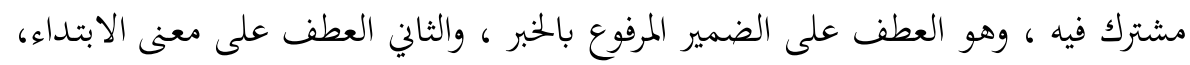

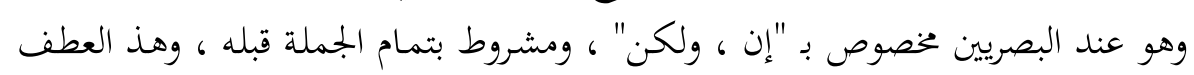

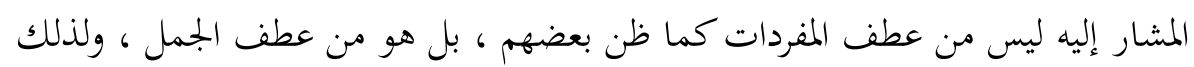

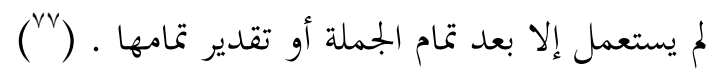




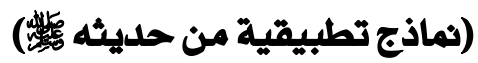

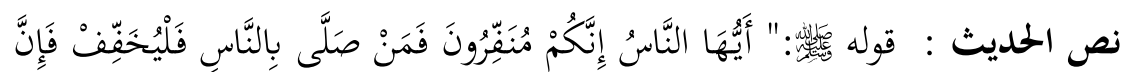

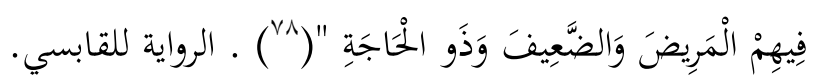

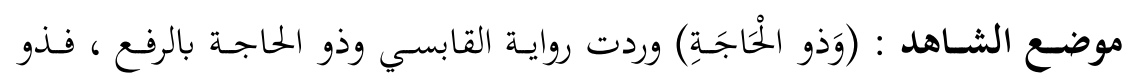

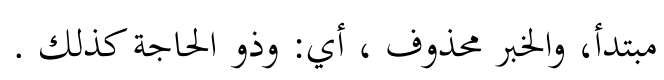

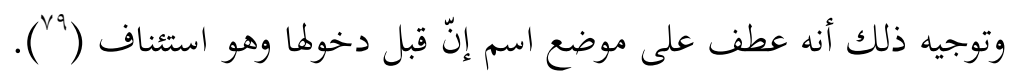

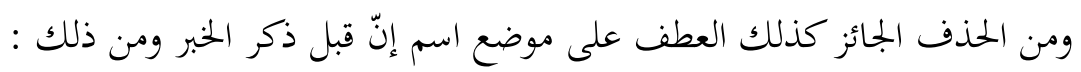

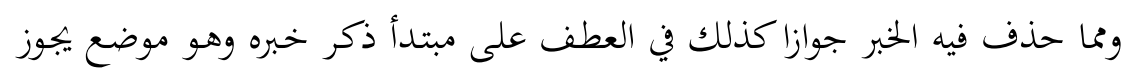

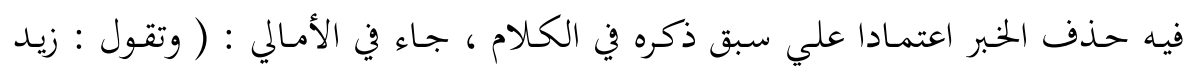

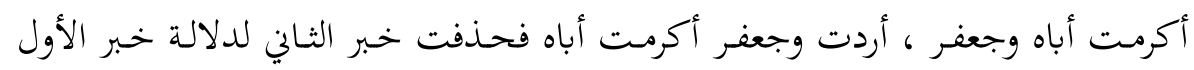

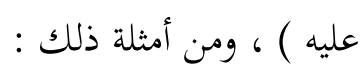

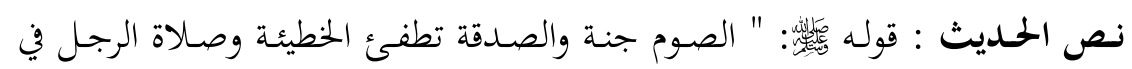

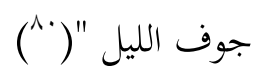

موضع الشاهد : (وصلاة الرجل في جوف الليل) مبتدأ خبره محذوف ، أي صلاة الرجل في جوف الليل كذلك.

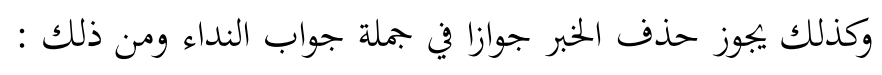
نص الحديث : " عن أبي عثمان النهدي عن حنظلة التميمي الأسيدي الكاتب قال

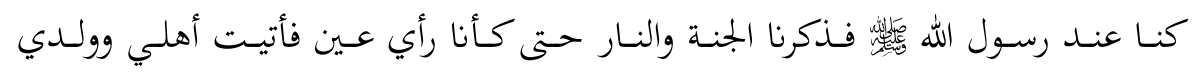

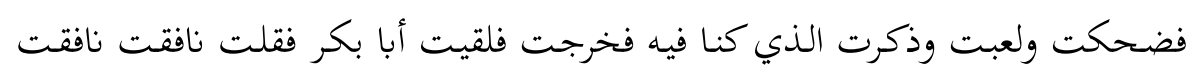

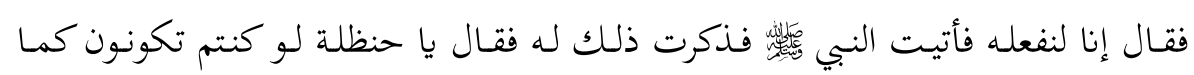

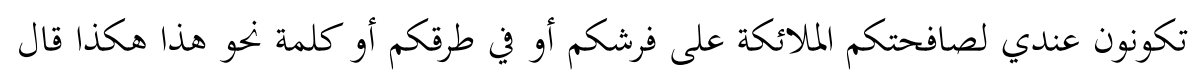

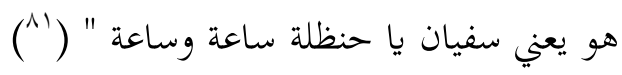

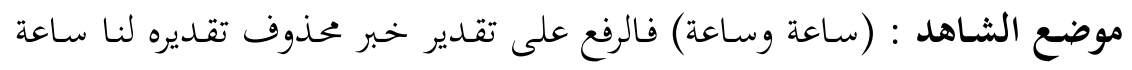

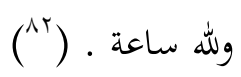
كذلك يحذف الخبر جوازا بعد حتى الابتدائية ، ومن شواهد ذلك : 


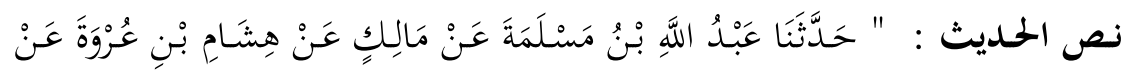

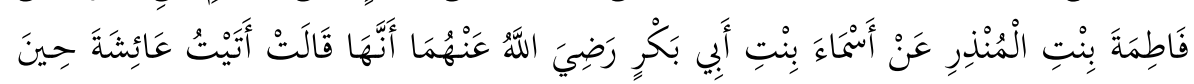

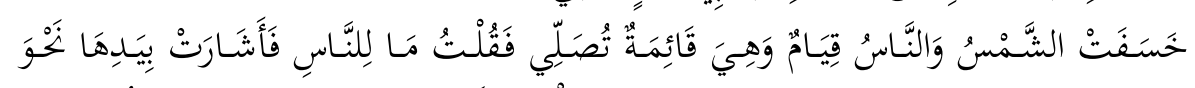

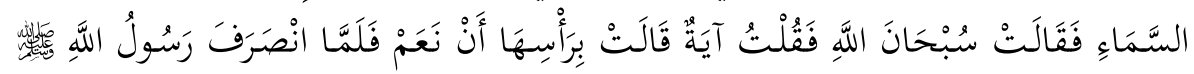

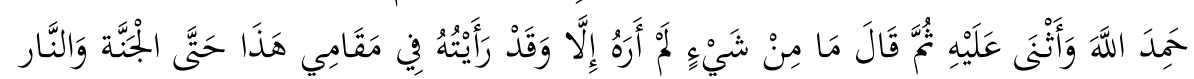

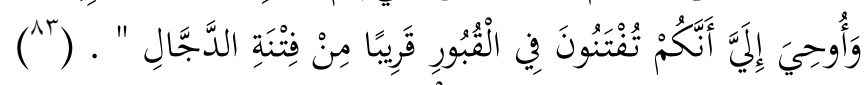

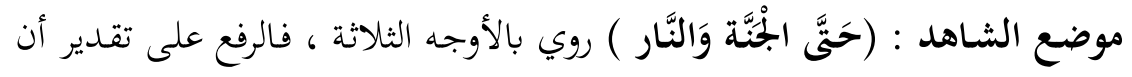

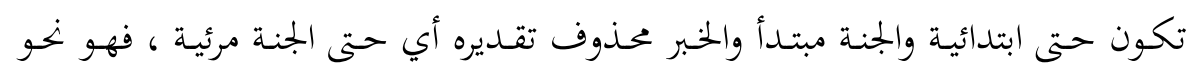

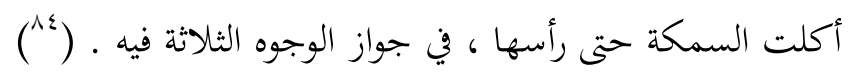

الخاتمة :

نخلص من هذا البحث إلى أن الحذف أحد ما يميز هذه اللغة العربية سواء كان في

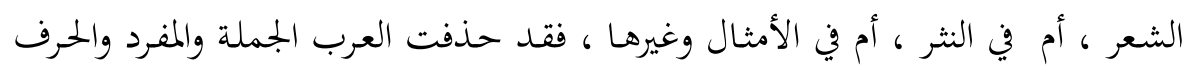
والحركة ، وقد استُعمل الحذف في معاني كثيرة وعلى رأسها الحذف للتخفيف وكان الهدف

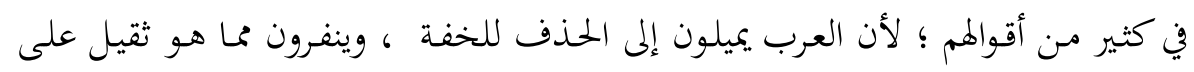
اللسان .

ومما بتحر الإشارة إليه أننا في كثير من الأحيان نقدر المحذوف مرتكزين على الذوق أو

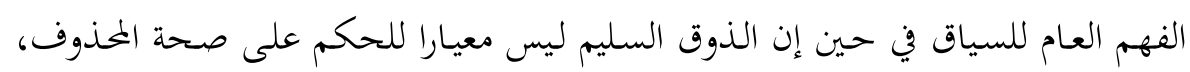
فلو سأل سائل : ما هذا بيدك ؟ قد ينكر الذوق ذلك ، في حين نجد هذا التعبير مشاكلا

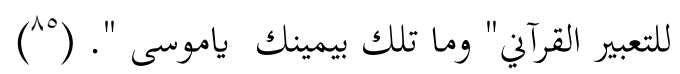

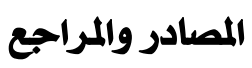

$$
\text { القرآن الكريم }
$$

1- ارتشـاف الضرب مـن لسـان العرب لأبي حيـان الأندلسي، تحقيق د. رجـب عثمـان محمـد، طا

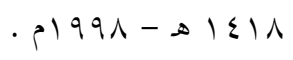

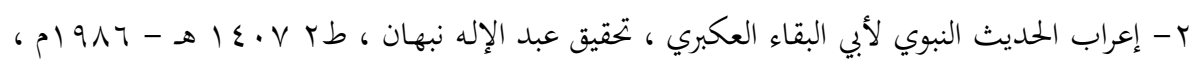

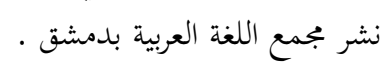

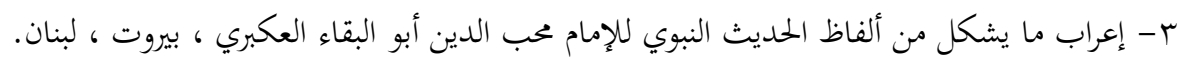

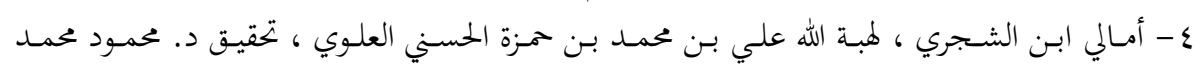

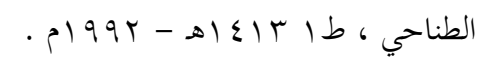




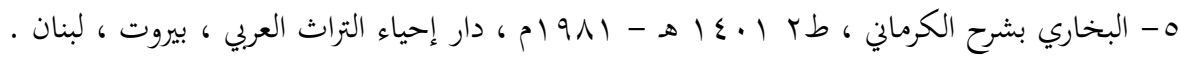

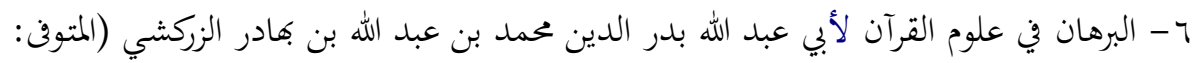

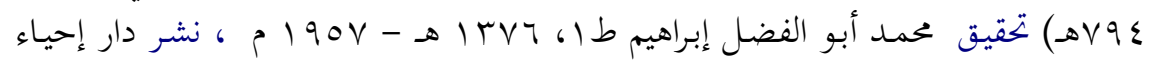

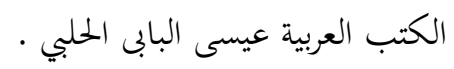

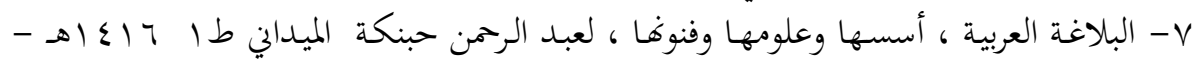
. 1997

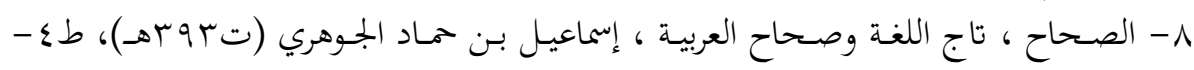

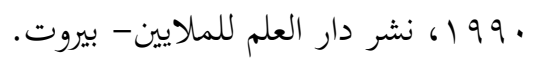

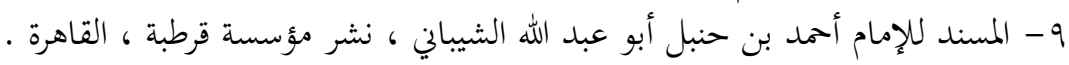

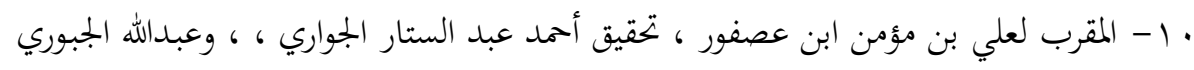

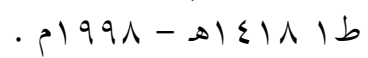

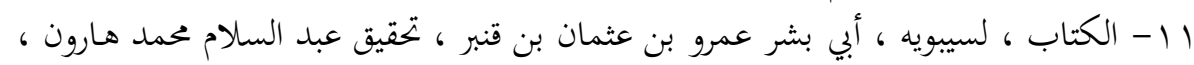

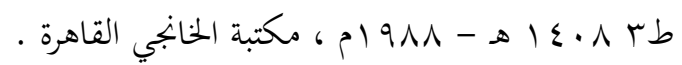

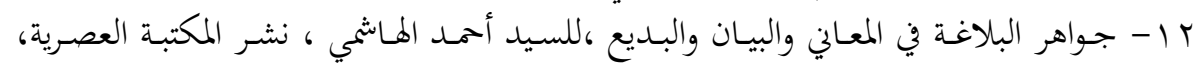
بيروت ، لبنان . البان

r ا- حاشية الصبان ، شرح الأشموني على ألفية ابن مالك ، تحقيق طه عبد الرؤوف سعد،

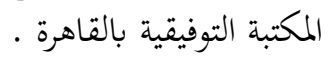

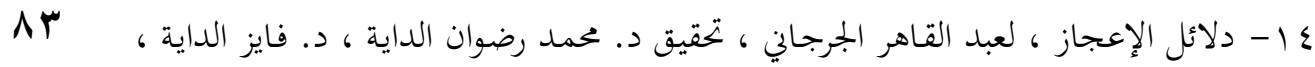

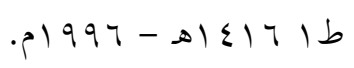

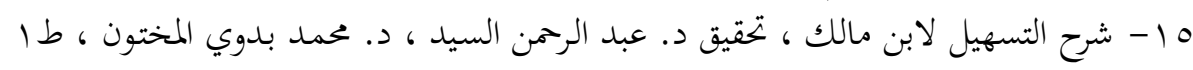

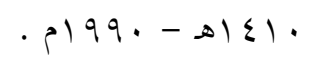

17

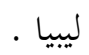
V ا - شرح الطبي على مشكاة المصابيح ، لشرف الدين الحسين بن عبدالله الطيبي ، تحقيق د.

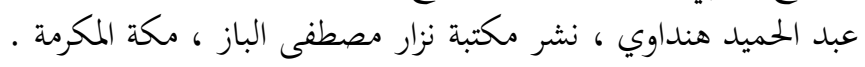

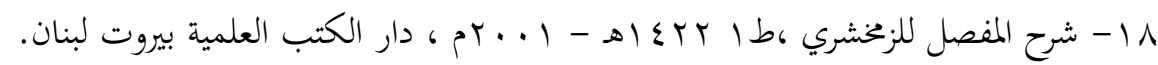

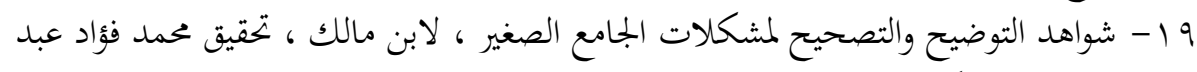

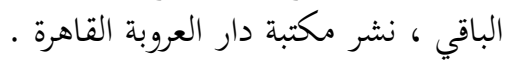

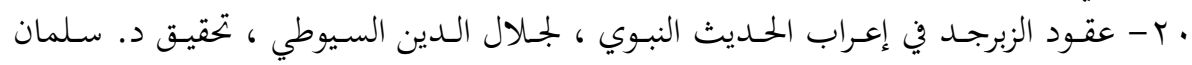

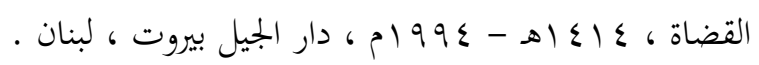

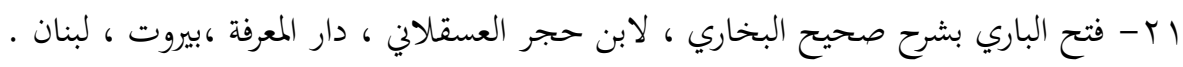

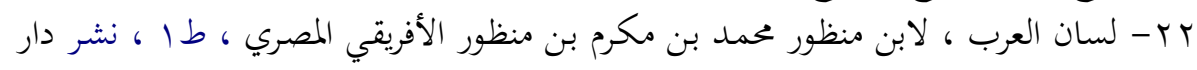

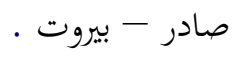




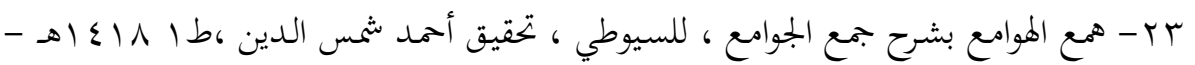

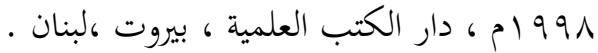

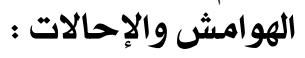

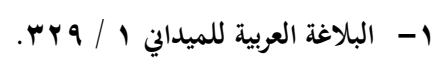

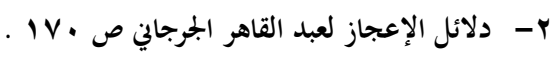

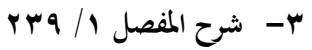

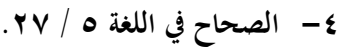

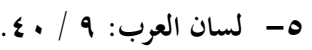

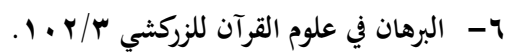

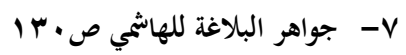

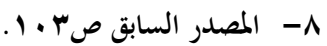

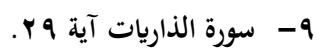

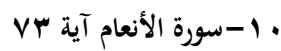

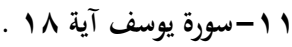

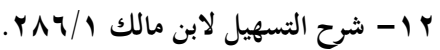

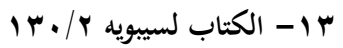

$$
\begin{aligned}
& \text { ع ا-المصدر السابق YNV/T }
\end{aligned}
$$

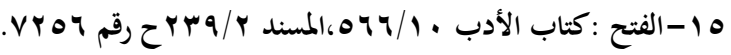

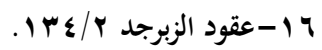

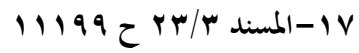

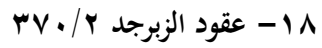

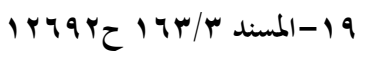

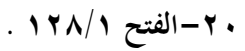

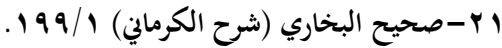

$$
\begin{aligned}
& \text { r r r r الفتح } \\
& \text { ك } \\
& 1000 \text { • }
\end{aligned}
$$

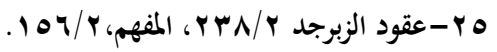

$$
\begin{aligned}
& \text { צ צ- - المسند }
\end{aligned}
$$

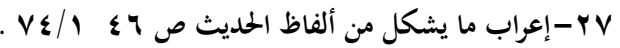

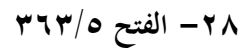

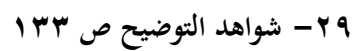

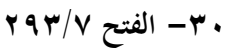

$$
\begin{aligned}
& \text { ا و }
\end{aligned}
$$




$$
\begin{aligned}
& \text { rا } \\
& \text { צr }
\end{aligned}
$$

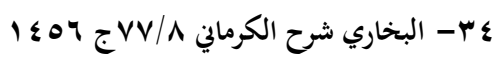

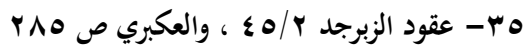

$$
\begin{aligned}
& \text { Var } \\
& \text { A } \\
& \text { A } \\
& \text { q }
\end{aligned}
$$

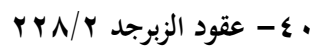

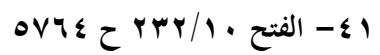

$$
\begin{aligned}
& \text { Y r } \\
& \text { VTVq ع ع }
\end{aligned}
$$

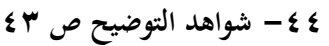

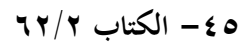

$$
\begin{aligned}
& \text { Y צ - شرح المقرب / } \\
& \text { Y } \\
& \text { A } \\
& 9
\end{aligned}
$$

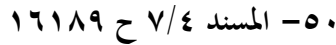

$$
\begin{aligned}
& \text { I }
\end{aligned}
$$

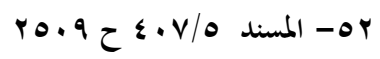

$$
\begin{aligned}
& \text { rه } \\
& \text { צ }
\end{aligned}
$$

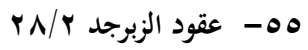

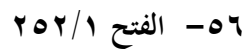

$$
\begin{aligned}
& \text { r }
\end{aligned}
$$

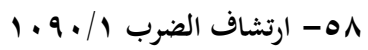

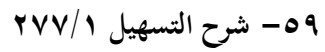

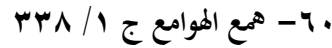

$$
\begin{aligned}
& \text { IrV/T }
\end{aligned}
$$

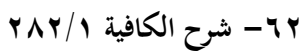

$$
\begin{aligned}
& \text { r } \\
& \text { צ } \\
& \text { PVN/ } \\
& \text { צ }
\end{aligned}
$$




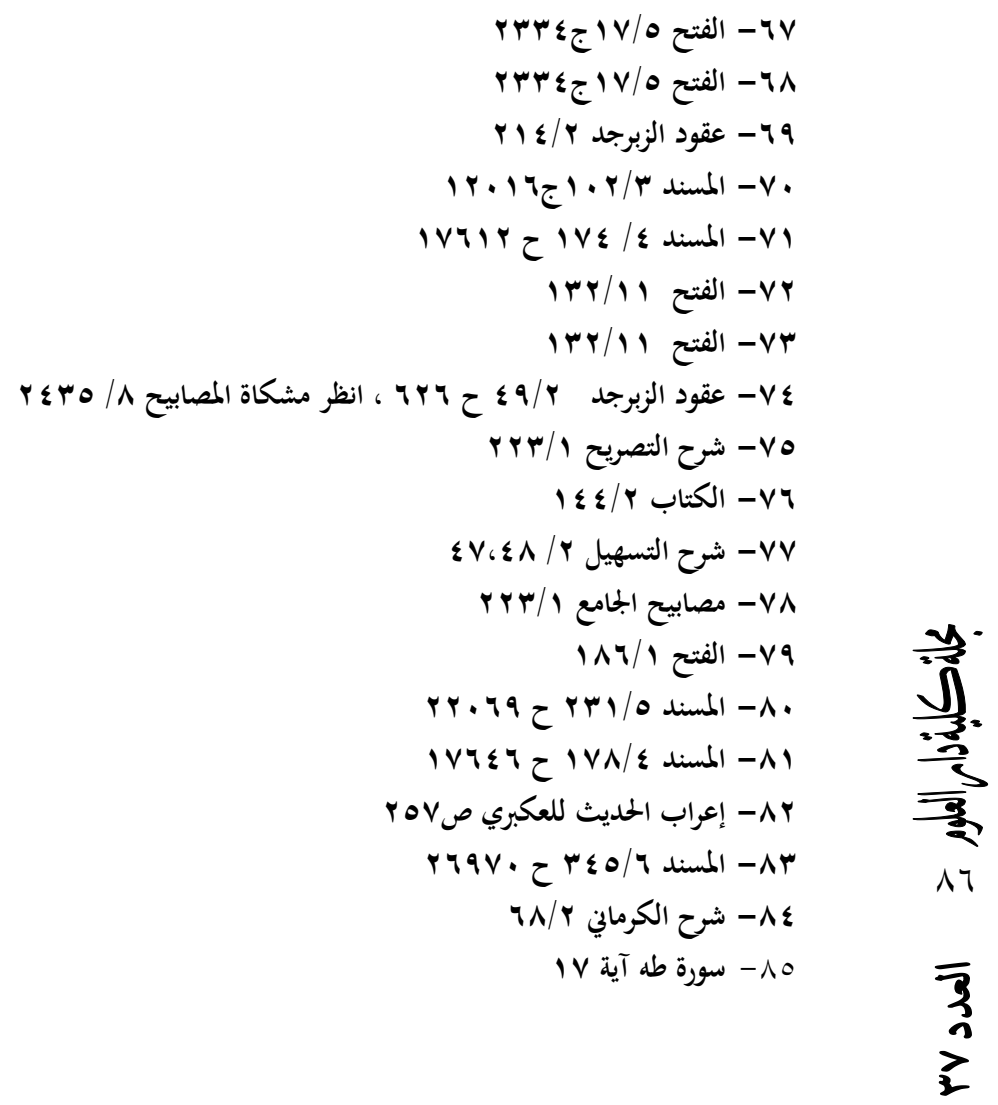

